\title{
God's victory and salvation. A soteriological approach to the subject in apocalyptic literature
}

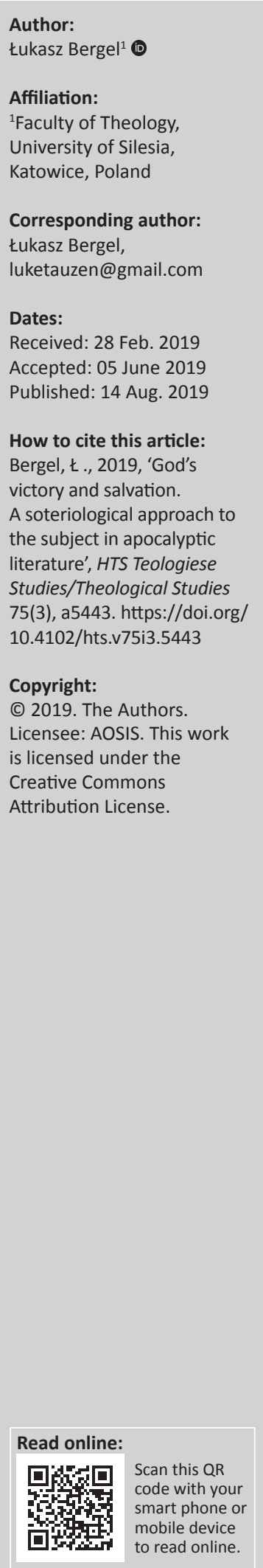

One of the main points of interests in the apocalyptic literature is the salvation of God's people. The topic is shown from a variety of perspectives. One of them is exceptional and very prominent in the apocalyptic genre - this is God's victory. The theme of victory is a complex one. It consists of not only terminology and imagery of war, fight, rivalry, but also judgement, competition and kingdom. All of these motifs are being intertwined in the apocalyptic victory of God. The problem of God's victory can be seen as schematic, which is present in many texts from the apocalyptic genre. Altering variables inside this scheme results in a different outlook on the salvation. It is used to give the shape of the narrative in the text. From the variety of apocalyptic literature, an exceptional place is given to the Apocalypse of John. The theme of God's victory there, although it uses the Jewish traditions, is rewritten and upgraded to a new unique form. The goal of this article is to investigate how the mentioned schematic realises through different examples of apocalyptic texts and how it is incorporated and redefined in the Book of Apocalypse. What is God's victory? Who is being conquered? With what means? What does it all mean to the salvation of people? These are the questions, which the author will try to answer in the article.

Keywords: Salvation; Victory; Apocalypse; Soteriology; Jewish apocalypticism.

\section{Introduction}

The topic of God's victory gives shape to the narrative of John's Apocalypse. The book is embedded in the language and imagery of war and rivalry. ${ }^{1}$ The term 'overcomer' (or 'victor') and descriptions of victory appear frequently and are attached to a number of figures. In this manner, the narrative reveals a specific vision of salvation, ${ }^{2}$ as a result of a fight that is waged by God for humanity (Bauckham 1993a:210-214).

The main goal of this study is to point out the essential differences of the vision of salvation between the Apocalypse of John and the Jewish apocalyptic literature through the perspective of God's victory topic and its comparison in the mentioned earlier texts. Who is God conquering and with what means? What are the consequences for salvation? A strict relation can be seen between a text soteriology and the way it presents the idea of God's victory. The way God gains victory over his adversaries and who those are affect the understanding of salvation. The Book of Apocalypse, while deeply embedded in the Jewish apocalyptic tradition, essentially rethinks and develops the vision of salvation by a modification of God's victory picture. This study examines the realisation of this relation.

The topic of God's victory is often raised in commentaries and works about the Apocalypse or apocalypticism in general. Often it is identified as a key element of the narrative and imagery (eds. Barton \& Muddiman 2001:1291-1303). Some devotional works concerning the Book of Apocalypse point to the imagery of victory as the main interpretational framework and exhortation to the Christian community about the significance of hope in God's triumph over the enemies (Shepherd 2011:15-36). Taking into consideration this interest in the topic, it is evident that the issue deserves closer examination within its own hermeneutics, specifically in the soteriological context. Study of the aforementioned relation between the image of God's victory and the vision of salvation in the text shows an innovative approach to the problem.

From the variety of authors touching the subject, two of them deserve mentioning for their complex look on the topic of salvation in the Book of Apocalypse. R. Bauckham made a great

1.The word veow and its derivatives occur 17 times in the Revelation $(2: 7,11,17,26 ; 3: 5,12,21 ; 5: 5 ; 6: 2 ; 11: 7 ; 12: 11 ; 13: 7 ; 15: 2 ; 17: 14 ; 21: 7)$. For comparison in the other NT writings: 1 John - six occurrences (2:13-14; 4:4; 5:4-5), Rom - 2 (3:4; 12:21), John - 1 (16:33) and Luke - 1 (11:22). To see more on the use of the word in NT, cf. Shin (2007:208-211).

2.Victory can be even identified with salvation in the context of Rev. Du Rand (2005:469-470). 
contribution to the soteriology of Apocalypse at all. His monographies concentrate on the symbolism incorporated into the book. Using a complex approach, he discusses a major set of imagery: the theocentric phrases, the Christological images, the prophecies, the New Jerusalem and the role of the Lamb's victory.

Bauckham states that the main task of Christ in Apocalypse is the establishment of God's kingdom on earth. ${ }^{3}$ This is accomplished through salvation and judgement. The theological imagery of Christ's work is incorporated in themes of holy messianic war, the new exodus and the witness (Bauckham 1993b:67-73).

God's ultimate victory over sin is realised through Christ's sacrificial death. The messianic war is presented similarly to Jewish apocalypses. There is the Anointed One - the warrior king - and his army. Then again, it is evolved in comparison to Jewish apocalypticism. Messiah's victory is not a militant one, but by sacrifice, and the army consists of martyrs, not of warriors. According to Bauckham, Christ's victory on the cross is the central event of Apocalypse's soteriology and a basis on which God's ultimate victory is realised (Bauckham 1993b:73-75).

The other work worth of mentioning is of J.A. du Rand, where the author discusses overall soteriology of the Apocalypse. It is pointed out that the book itself has a soteriological structure, and its eschatology is shaped by its soteriology (Du Rand 2005:482-484). Again, Christ's death on the cross is presented as the decisive point of Apocalypse's vision, and the goal is 'to acknowledge God's rule on earth as it is already recognised in heaven' (Du Rand 2005:468). Therefore, the following division can be constituted. A soteriological accomplishment, which consists of all the works done by the Lamb to procure salvation to humanity, and the soteriological consequences, which concentrate on describing God's and Lamb's actions to appropriate the salvation to the whole world (Du Rand 2005:472-476). Du Rand surveys soteriological terminology and reveals that 'victory' in the book works as a synonym to 'salvation', and even both of these terms can be identified (Du Rand 2005:470).

To achieve the main goal of this article, an initial emergence of God's victory theme is proposed in the first part. The second part concentrates on pointing out the realisation of the theme in Jewish apocalypses to build a base of discussion for the last part, which shows this theme in the Apocalypse and how it is used and redefined.

\section{The scheme of victory}

Soteriology in apocalyptic literature is often presented in two aspects: the salvation and the judgement. ${ }^{4}$

3.Establishment of God's kingdom is a general concentration of apocalypticism at ali. See Russell (1964).

4.They are the sequence of steps and the two sides of the soteriological process. See Du Rand (2005:472).
These two issues are characteristic of the apocalyptic genre and are mutually connected. In their essence, they seem to stand in opposition, but in apocalyptic reality, they are complementary. Salvation concerns the salvific process - the events and actions that must be done - and the results of this process. ${ }^{5}$ The judgement is showed as a consequence of the refusal of salvation.

The terminology and imagery of God's victory can be related to both aspects. However, it is usually applied to the salvific aspect and even identified with it (Du Rand 2005:470-473). Salvation is a victory. This is often pointed out as the main message of Apocalypse (eds. Barton \& Muddiman 2001:1302). It is full of descriptions of the fight, which is conducted by God, for his people.

From this imagery, we can conceive a general scheme of victory. God is always the ultimate victor. Then, there is a type of adversary. There are some means by which God gains his triumph. At last, there are the consequences of this fight.

\section{The Jewish apocalypses}

A general structure of God's victory has been already constituted, as a perspective on understanding apocalyptic soteriology. A scheme, by which God's victory could be described, has also emerged. In the following step, we shall investigate, using a synchronic approach, how this scheme is realised in apocalyptic texts.

All the apocalyptic texts are consonant in one aspect of God's victory - it will be ultimate and will bring an everlasting kingdom of God (Bauckham 1993b:67; Russell 1964:285-286). The means of victory, its reach and character, however, differ in those texts widely. In this part of the study, we will concentrate on presenting how the idea of God's victory is shown in different apocalyptic texts. Because the goal of this paper is to investigate the differences of God's victory between the Jewish apocalypses and the Apocalypse of John, we will concentrate on those texts that precede the redaction of the latter and may have influenced the author. ${ }^{6}$

The majority of texts describing God's victory say that it is the only way to establish his kingdom - that itself is a picture of salvation for people. This picture changes along with the change of victory aspects. The most notable of these aspects is the mediation of messianic, angelic or human figures. Indeed, it is possible to divide the presentation of texts by God's sole victory and a triumph through mediators. Firstly, we shall discuss the texts without any mediation and then the other group. ${ }^{7}$

5.This is a reference to the soteriological structure of Apocalypse, mentioned before. Du Rand (2005:468-482).

6.As the date of John's Apocalypse, we will take the most popular approach - the end of 1st century CE. More on the date, see Wood (2016:110-185).

7.The order of text presentation refers to the order of J.H. Charlesworth work. See Charlesworth (1983). 
God's victory can be seen as his own, sole action, without messianic, angelic or human mediation. Such a vision can be found in Book 2 of Enoch (2 En). ${ }^{8}$ God's main antagonist is the Satanail (2 En 18:3, 31:3-6). ${ }^{9}$

He aspires to become equal to God and rival him (2 En 29:4). $\mathrm{He}$ is also responsible for the corruption of Eve (2 En 31:6). God casts him and his followers away from the heavens, and they are forced to fly unstoppably over the Bottomless (2 En 29:5). Everything takes place in heavens, and God's victory over Satanail precedes the creation of men. Satanail with his associates, being imprisoned, awaits the final judgement from God (2 En 7:1-2, 18:1-3).

A more popular idea of God fighting for his people can be found in the Apocalypse of Abraham (ApAb). ${ }^{10}$

God announces that he will destroy every nation who mocked him and his chosen ones, and they will be burned by fire and thrown to Hades (ApAb 31:1-3). The enemies of Israel are enemies of God.

This schematic of God fighting for his people is present in the Book of Jubilees $(\mathrm{Jub})^{11}$ as a reminiscence and reinterpretation of Genesis and Exodus. The main antagonist of God and his people here is Mastema, the prince of demons. Throughout the book, he is presented as the one responsible for all the evil in the world, the one who incites people's hearts to sin. His demons led the children of Noah to sin and folly (Jub 10:1). On behalf of Noah, God commanded binding of the ninetenths of the demons and throwing them into the place of judgement (Jub 10:7-11). He is also the one who instigated the pharaoh to pursue Israel, but God defeated Mastema, throwing Egyptians into the depths of the sea, and shamed the prince of evil (Jub 48:9-19). Soteriology of the book is concerned about God's actions to restore a proper relationship with his people and the defeat of the source of evil, the cause of damage to this relation.

The other form of God's victory is with the participation of a messianic figure, an angel or even an army of people. They serve as the agents of God's will. They execute his judgement and destroy the opposition.

The discussed topic is prominent in Book 1 of Enoch (1 En). ${ }^{12}$ The book opens with a vision of God's victory march. God himself marches to his people to bring salvation for

8. It is very difficult to pin down the date of 2 Enoch. Some suggestions were made that it could be a medieval compilation, but even so, the material used to compile it must have been earlier. We cannot exclude that, at least, parts of it were already known in the 1st century CE (as it is often assumed). Therefore, it is included in this section. For the whole argument, see Andersen (1983:94-97).

9.In this point, it should be clarified that there are two recensions of 2 Enoch: the longer and the shorter. The personification of the enemy, his name and story of his fall is present only in the longer recension. See Andersen (1983:93-94).

10.As the date of this book, we assume the period of $70 \mathrm{CE}$ to the middle of the second century. See Rubinkiewicz (1983:683).

11.The date of this book should be set between 161 and 140 BC. See Wintermute (1985:43-45).

12.The 1 Enoch final compilation is usually dated at the end of 1st century CE. See Isaac (1983:6-7). them (1 En 1:3-4). The soteriology of the book concentrates on establishing an everlasting kingdom of God. The main antagonist here is identified as Azazel who 'taught the people the art of making swords and knives, and shields, and breastplates' (1 En 8:1) - the instruments of war. He is also blamed for showing people the ways of injustice and corruption, and the rulers how to oppress the righteous, the people of God, who acknowledge his authority over the world. The other antagonists are the kings, the rulers and the landlords. They do not recognise God as a source of their kingship and they deny his name. They are shown as the associates of Azazel and they form his armies (1 En 53:3-5). In a pre-specified time, God will reveal the Elect One, the Righteous One or the Son of Man, ${ }^{13}$ who 'is destined to be victorious before the Lord' (1 En 46:3). He is the main agent of God's victory. He will remove all the rulers from their thrones and make them fall on their faces before the Lord (cf. 1 En 46:3-7; 48:10). Then, Azazel and his armies shall be bound by chains and thrown into the darkness, waiting to be judged by the Messiah (cf. 1 En 10:4; 54:4-5; Rv 20:1-3). As an outcome of God's victory over his enemies, every sin shall be destroyed from the surface of the earth and every sinner will be cut off by the sword. The instruments of war, the creation of Azazel, will be removed from the world. The righteous will enjoy eternal light, joy and uprightness, and will be given the garments of glory (1 En 62:15).

The Sibylline Oracles $3(\text { SibOr } 3)^{14}$ soteriology is characterised by a great war and transformation of the world. God shall destroy the old things distorted with sin and its corruption (SibOr 3:81-92). The representation of the opposing forces is Babylon and Egypt, the oppressors of Israel. God will inflict destruction over every nation that raised their hand over the chosen people (cf. SibOr 3:307-318). The greatest enemy of God is Beliar. When he comes, he will do many miraculous signs, like raising the dead, and many people, also the chosen Hebrews, will fall into his deception (cf. Rv 13:13-14). God will destroy him with burning power (SibOr 3:71-74). To save Israel, God will send a king (SibOr 3:286-294; cf. Collins 1983:357). He will wage war against other nations to judge them and subdue them to God's solely reign (SibOr 3:611$618,652-656)$. When God's great war will be accomplished with his victory, the whole world will be transformed (SibOr 3:619-623), his elect people will live peacefully around the temple (SibOr 3:702-709) and God himself will guard them and fight for them, so they could be free from evil and war forever.

The Book 4 of Ezra (4 Ezra) $)^{15}$ outlook on salvation is one of the most universalistic in comparison to other Jewish traditions. Israel is the chosen nation, but every man that is frightful of God will be saved from the coming calamities. God's gifts and actions towards Israel are to establish a

13.The book uses the three of these terms on several occasions (see 1 En $38: 2 ; 39: 6$; 46:3). See Isaac (1983:9).

14.The SibOr 3 consists of three stages: (1) Verses $97-349$ and 489-829- dated in the period 163-145 BC; (2) Verses 350-488 - dated before 31 BC; (3) Verses 1-96considered as the latest part and in its final form dated after $70 \mathrm{CE}$. See Collins (1983:354-361).

15.4 Ezra is dated usually around 100 CE. See Metzger (1983:520). 
kingdom of righteousness and to destroy every sin and corruption from the face of the world (4 Ezra 6:25-28, 16:52-53). God will fight his enemies, represented again as Babylon, Egypt, Syria and Asia (4 Ezra 16:1-17). To gain victory, he will send a messiah, a Man of Sea. This figure will gather the remnants of Israel and every people loyal to God. Messiah will destroy God's enemies with fire coming from his mouth (4 Ezra 13:1-13, 25-50; cf. Rv 19:11-21). The rest of the people shall live in peace defended by the victorious Messiah.

The soteriology of the 2 Baruch (2 Bar $)^{16}$ overall shares the apocalyptic vision of a world that is corrupted by sin, therefore must be destroyed and created anew. God's victory theme is seemingly absent in the book. Only a few significant mentions can be found in 2 Baruch 40:1-4 and 63:6-11. In the first, the Anointed One will destroy the hosts of enemies of Mount Zion. He will bind and convict the last opposing king for all his evil deeds. The second image is composed of vision of God sending his angel to destroy the multitudes of Assyrian armies, to save the rest of Israel that stands on Zion. As we can see, the imagery of God's victory concentrates on saving God's chosen nation from his enemies and the tribulation that shall come upon the world.

The Testaments of 12 Patriarchs ${ }^{17}$ are more concerned about the spiritual fight that is waged by every person than about eschatological kingdom. The source of evil and the main adversary of God and men is Beliar. He is the one who leads human to sin and incites promiscuity. God will wage war against him at the end of the time and will be victorious, and all captives taken by Beliar will be released (TDan 5:10-13). Levi and Judah are the main agents of God's victory, taking a messianic role for Israel (TSim 5:5-6). The salvation will come from their tribes and they will defeat Beliar (TDan 6:3-4, TLevi 18:12). Then God will be revealed to all nations. Levi and Judah will stand as a light for Israel and every nation.

\section{The Apocalypse of John}

The Apocalypse of John employs the discussed imagery and elevates it to a new level. The followed schematic of God's victory is present throughout the narrative of the book. God is undoubtedly the ultimate victor. The Messiah is the mediator. There is also the opposition. All of these images are reconsidered and forged into a new form.

The role of the Messiah is developed significantly. He is the main executioner of God's victory. Two portrayals of Christ are present and each has its own specific role in the scheme of God's victory.

The first portrayal of Christ shows him as a Lamb (Rv 5:1-10). His nominal description as 'a Lion from the tribe of Judah, the Root of David' (Rv 5:5) lies firmly within the apocalyptic view of the Messiah as a military victor (Bauckham 1993a:213-215). However, the contrasting image of the Lamb

16.2 Baruch is usually dated in the period of $70 \mathrm{CE}$ to the second decade of the 2 nd century CE. If the earlier date is correct, the material could have been partially known to the author of John's Apocalypse. See Klijn (1983:616-617).

17.Dated in early 2 nd century BC. See Kee (1983:777-778). indicates a new look into this scheme. The image of lamb would be typically associated with the Passover sacrifice. In this juxtaposition of two images, that seem to stand in contrast, a new form of victory is formulated (Rosell 2011:3). It is a victory over evil by sacrificial death (Bauckham 1993b:73-75; Shin 2007:215). By his sacrifice and resurrection, the Lamb is worthy to take the scroll and break its seals. ${ }^{18}$ This is a complete novelty in comparison to Jewish apocalyptic traditions. Furthermore, in Jewish traditions, the messianic victory was something expected in the indefinite future. The Apocalypse shows that this decisive event has already been completed and, by this act, God's ultimate victory is made possible (Bauckham 1993b:67-73).

The second portrayal of Messiah presents him as a rider on a white horse, 'the King of kings and Lord of lords' ( $R v$ 19:11-21). In this depiction, victory is combined in the imageries of war and judgement (Bauckham 1993b:104-106). Christ is shown as a Divine Warrior accompanied by his armies. A battle breaks out between God's forces and his enemies. But Christ is fighting with the sword coming from his mouth. This is a reference to a judicial sentence and the Messiah's role of a judge (e.g. 4 Ezra 13:1-13). God's victory here is gained through the punishment of those who rejected his salvation.

God's opposition in Jewish apocalypses consisted traditionally of two forms: a spiritual enemy (Satan) and worldly (kings, gentiles). Both images are incorporated into the Apocalypse.

The spiritual enemy emerges in Revelation 12:3, portrayed as a Dragon, and in Revelation 13:1, 11, portrayed as the beasts. The image used here is a complex combination of a variety of Jewish traditions. ${ }^{19}$ Their primary activity is the deception of the nations of the world ( $\operatorname{Rv} 12: 9 ; 13: 14)$. This satanic trinity is presented as the supernatural opposition and rival to God (cf. 2 En 29:4) and the enemy of his people ( $\operatorname{Rv} 12: 17 ; 13: 7)$. The Dragon acts also as an accuser of the saints ( $R v 12: 10)$. He revolts in heaven against God in an attempt to devour the Woman's child. His plan is apprehended by Michael's intervention and the Dragon is thrown down from heaven (Rv 12:7-10; cf. Shin 2007:213-214).

The worldly enemy is portrayed as Great Babylon, the harlot (Rv 17:3-5). This image represents the political opposition of God in this world because it has power over kings ( $\operatorname{Rv} 17: 18$; cf. Bauckham 1993b:126-132).

The combination of both oppositions creates a strong message about God's victory. It will be universal, both in this world and the transcendent aspect. Every enemy will be ultimately thrown into the lake of fire ( $R v$ 19:20-21). The

18.The act of taking the scroll can be seen as a transfer of authority and power to conquer and judge. Through his death and resurrection (the victory over death) conquer and judge. Through his death and resurrection (the victory over death), Christ is set as the main executioner of God's victory, which is a significan development of Messiah's role in comparison to Jewish apocalypses. See ed.
Carson (1994:1433); Rosell (2011:4). 19.For a more comprehensive description on the topic, see Bauckham (1993a:185-198). 
Dragon will attempt to make his last stand and fight with the saints ( $\operatorname{Rv} 20: 7-10)$, but then God will make his final move and send his fire to consume the rest of his enemies (Bauckham 1993b:106-108). God's ultimate victory will become realised and his rule over the world will be unquestionable. No evil, darkness, death and tears will be in his kingdom.

The result of God's victory is the descent of New Jerusalem and the creation of new heaven and earth ( $R v$ 21:1-2.5). In this recreated world, God will dwell among his people ( Rv 21:3). Humans would not be ever separated from their Creator and there will be no tears, death, grief or pain ( $\mathrm{Rv}$ 21:4). People will stay in unending liturgy and adoration of God (Rv 22:3-4).

It is possible to see how the Apocalypse uses Jewish traditions. The images known in the apocalypticism were transformed into a new message. Firstly, we shall discuss the role of the Messiah. Traditionally, he is the leader of God's armies and the destroyer of his opposition. This image is present in the Apocalypse, but in a new form. The victory is not achieved by violence, but by the sacrificial death and resurrection of Christ. This is a decisive point, which makes God's ultimate victory possible to be realised (Bauckham 1993a:215). Also, this is not something to be expected in the future, as the Jewish apocalypses have, but it is already done - the victory is already in motion (Bauckham 1993b:75).

The scope of the triumph is also more extensive. The Jewish apocalypticism usually restricts the salvation to the nation of Israel and, sometimes, to the believers from the gentiles. Here the army of victors consists of the innumerable crowd from every nation, tribe and language (Bauckham 1993b:74). This universal availability of salvation in Apocalypse carries an ethical call to the reader. Everyone, who worships God and is faithful to his word, will have his share in this victory (Rv 21, 7; cf. Bauckham 1993b:98-106).

\section{Conclusion}

God's victory imagery is used lavishly throughout the apocalyptic genre. It is one of the main concepts presented in this literature. It serves as the main engine of the narrative and conveys an important message about human salvation. It is possible to point a scheme of God's victory that is realised in different approaches in the apocalyptic literature. In one instance, God is a sole victor - his triumph is gained without any other involvement. Otherwise, this victory is attained by the action of a Messiah, angels or human armies. Means to achieve triumph are also differentiated. There are images of military conquest, and again the destruction of the enemy is shown as an execution of a sentence.

The methods of victory are different, but the goal is one - the salvation of God's chosen people. Here the scope of salvation can be various. God's victory can concern only the sons of Israel. In other instances, this election is stretched to all people of good will, from any nation and language.

The opponents of God can also be presented twofold. The enemy can be spiritual - one of God's primaeval creation, which diverted from its Creator - presented as a supernatural source of every sin and wickedness of men. The second presentation consists of worldly, political power, oppressing God's people and in this way neglecting God's authority.

The Apocalypse incorporates these images and forges with it a new vision of God's victory - not with violence, however the language used may suggest otherwise, but of sacrificial death and resurrection of the Messiah. The time of realisation also is transformed because the decisive victory of Christ has been already won. Also, the scope of the victory is extended. In most cases, Jewish apocalypticism restricts salvation to the nation of Israel. The Apocalypse shows a universal victory of God, a victory over every opposition (spiritual or worldly), which is available for any faithful people from every nation. This again carries a call to be faithful to God's word to be granted a share in his victory.

\section{Acknowledgement}

The author would like to thank Prof. Artur Malina from the University of Silesia in Katowice, Poland, for all his guidance and suggestions considering the research. He would also like to thank the Dean of the Faculty of Theology for his procedural support.

\section{Competing interest}

The author declares that no competing interest exists.

\section{Author contributions}

I declare that I am the sole author of this research article.

\section{Funding}

This research received no specific grant from any funding agency in the public, commercial, or not-for-profit sectors.

\section{Data availability statement}

Data sharing is not applicable to this article as no new data were created or analysed in this study.

\section{Disclaimer}

The views and opinions expressed in this article are those of the authors and do not necessarily reflect the official policy or position of any affiliated agency of the authors.

\section{Ethical consideration}

This article followed all ethical standards for carrying out research without direct contact with human or animal subjects. 


\section{References}

Andersen, F.I., 1983, '2 (Slavonic Apocalypse of) Enoch: A new translation and introduction', in J.H. Charlesworth (ed.), The Old Testament pseudepigrapha: Vol. 1: Apocalyptic literature and testaments, pp. 91-221, Doubleday, Garden City, NY.

Barton, J. \& Muddiman, J. (eds.), 2001, The Oxford Bible commentary, Oxford University Press, Oxford.

Bauckham, R., 1993a, The climax of prophecy: Studies on the Book of Revelation, T \& T Clark, London, New York.

Bauckham, R., 1993b, The theology of the Book of Revelation, Cambridge University Press, Cambridge.

Carson, D.A. (ed.), 1994, New Bible commentary: 21st century edition, InterVarsity Press, Downers Grove, viewed n.d., from https://accordance.bible/link/read/IVPNB_Commentary\#17830.

Charlesworth, J.H., 1983, 'Introduction', in J.H. Charlesworth (ed.), The Old Testament pseudepigrapha: Vol. 1: Apocalyptic literature and testaments, pp. 3-4, Doubleday, Garden City, NY.

Collins, J.J., 1983, 'Sibylline oracles: A new translation and introduction', in J.H. Charlesworth (ed.), The Old Testament pseudepigrapha: Vol. 1: Apocalyptic literature and testaments, pp. 317-472, Doubleday, Garden City, NY.

Du Rand, J., 2005, 'Soteriology in the Apocalypse of John', in J.G. van der Watt (ed.) Salvation in the New Testament: Perspectives on soteriology, pp. 465-504, Brill, Leiden.

Isaac, E., 1983, '1 (Ethiopic apocalypse of) Enoch: A new translation and introduction', in J.H. Charlesworth (ed.), The Old Testament pseudepigrapha: Vol. 1: Apocalyptic literature and testaments, pp. 5-89, Doubleday, Garden City, NY.

Kee, H.C., 1983, 'Testaments of the twelve patriarchs: A new translation and introduction', in J.H. Charlesworth (ed.), The Old Testament pseudepigrapha: Vol. 1 : Apocalyptic literature and testaments, pp. 775-781, Doubleday, Garden City, NY.
Klijn, A.F.J., 1983, '2 (Syriac Apocalypse of) Baruch: A new translation and introduction', in J.H. Charlesworth (ed.), The Old Testament pseudepigrapha: Vol. 1: Apocalyptic literature and testaments, pp. 615-620, Doubleday, Garden City, NY.

Metzger, M., 1983, 'The fourth book of Ezra: A new translation and introduction', in J.H. Charlesworth (ed.), The Old Testament pseudepigrapha: Vol. 1: Apocalyptic literature and testaments, pp. 517-524, Doubleday, Garden City, NY.

Rosell, S., 2011, 'John's Apocalypse: Dynamic word-images for a new world', HTS Teologiese Studies/Theological Studies 67(1), 5. https://doi.org/10.4102/hts. v67i1.832.

Rubinkiewicz, R., 1983, 'Apocalypse of Abraham: A new translation and introduction', in J.H. Charlesworth (ed.), The Old Testament pseudepigrapha: Vol. 1: Apocalyptic literature and testaments, pp. 681-688, Doubleday, Garden City, NY.

Russell, D.S., 1964a, The method \& message of Jewish apocalyptic, 200 BC-AD 100, SCM, London.

Russell, D.S., 1964b, The method and message of Jewish apocalyptic, pp. 285-303, SCM Press, Chatham, Kent.

Shepherd, R., 2011, Praise god, we won: A vision of victory from Jesus Christ in the revelation, West Bow Press, Bloomington, IN.

Shin, E.C., 2007, 'The conqueror motif in chapters 12-13: A heavenly and an earthly perspective in the Book of Revelation', Verbum et Ecclesia 28(1), 207-223. https:// doi.org/10.4102/ve.v28i1.104

Wintermute, O.S., 1985, 'Jubilees: A new translation and introduction', in J.H. Charlesworth (ed.), The Old Testament pseudepigrapha: Vol 2: Expansions of the 'Old Testament' and legends, wisdom and philosophical literature, prayers, psalms and odes, fragments of Lost Judeo-Hellenistic works, pp. 35-51, Doubleday, Garden City, NY.

Wood, S.J., 2016, The alter-imperial paradigm: Empire studies \& the Book of Revelation, Brill, Leiden, Boston, MA. 